\title{
Agata Szulc-Woźniak
}

(D) http://orcid.org/0000-0003-4473-7840

Instytut Filologii Polskiej, Uniwersytet im. Adama Mickiewicza w Poznaniu

\section{Wydobywając (żydowskość) Seweryna Pollaka}

\author{
„[...] jeszcze noszę tamtą ciemność” \\ Tożsamość
}

We wrześniowym wydaniu „Więzi” z 1991 roku opublikowano trzy wiersze Seweryna Pollaka. Choć powstały one w latach 50., brzmią jak summa jego niezwykle pracowitego i owocnego życia. Pośmiertny kontekst wyboru liryków nadaje refleksjom odcień ostateczności - jakby właśnie te myśli stanowiły kulminacyjny punkt twórczości, rejestrowały moment, w którym ślady niepokojów, poszukiwań stawały się niedoskonałą, ale już niezmienną, konkluzją. Ostatni z zamieszczonych utworów, niedatowany, zwraca uwagę w wyjątkowy sposób:

Szlam

Przyszedłem z kraju mrozu i płomienia, miałem zgrabiałe ręce, głowę ściskała mi obręcz ognista.

Ojciec mój stał za ciemną chmurą, która raz po raz falą przybijała do mnie, ojcowie moi matki moje, bracia i siostry stali za ciemną chmurą, co jak przypływ morza biła we mnie $\mathrm{z}$ uporem.

To nie muszle zostały na brzegu - szklane oczy, to nie fala płakała - płakali umarli, to nie wiatr we mnie uderzał - mój własny lęk. Byłem brzegiem i falą i muszlą szumiącą, byłem chmurą i lądem. 
Stałem na brzegu, z którego spłynęły wody, razem $\mathrm{z}$ innymi szlam odrzucałem, muł odrzucałem, przeorywaliśmy ziemię, aby siać w nią gwiazdy.

Czy kiełkowały gwiazdy i wschodziły, czy każda była niby kiełek blasku?

Wschodziły umarłe oczy, rosły z mułu umarłe oczy, a ja za nie wszystkie patrzeć musiałem na suche słońce - suchym spojrzeniem ${ }^{1}$.

Na tle poezji Pollaka przytoczony wiersz wyróżnia coś głęboko osobistego. Nie chodzi nawet o bezpośredniość wyznania - utwory autora Godziny życia krytycy zgodnie nazywają prywatnymi, wspomnieniowymi ${ }^{2}$, a nawet przywodzącymi na myśl „spowiedź samemu sobie”3. Tym razem jednak refleksja wydaje się bardziej ogólna, bardziej gruntowna - czyli sięgająca gruntu: tożsamości.

Rozpoczynająca liryk identyfikacja ze stojącymi za ciemną chmurą uruchamia lęk, który wrasta w świadomość przynależności. Niepokój nie odchodzi jest powracającą falą, niecichnącym, wciąż uderzającym wiatrem. Bycie sobą to tragiczne uwięzienie w grozie. Lęk jest wzmagany przez poczucie osobności. Historia się nie spełniła, ofiara się nie dokonała. Ocalony pozostał sam wobec potęgi żywiołów i bezmiaru śmierci. Ta właśnie samotność jest źródłem wstydu wstydu ocalonego, który w imieniu umarłych i zamiast nich musi mieć odwagę, by patrzeć „na suche słońce - suchym spojrzeniem”. Szklane, umarłe oczy, oczy wschodzące, rosnące z mułu, są jak obsesje surrealistów, André Bretona i Victora Braunera - dla samotnego na brzegu morza stają się koszmarem przeczącym prawom życia.

Wizja Pollaka nawiązuje do biblijnego, pierwotnie czystego obrazu - oto morze rozstępujące się przed Izraelitami uciekającymi z Egiptu. Potęga Jahwe, prowadzącego swój lud z ziemi niewoli, umożliwia tryumfalne przejście między ścianami żywiołu. U Pollaka jednak spłynięcie wód odsłania tylko szlam, muł oraz rozkład. Przypomina o dołach, które kopali skazani, o brudnej śmierci. O odrazie.

Szlam to niejedyny wiersz, w którym poeta mówi o swoim pochodzeniu i niejedyny, gdzie cień Zagłady niesie myśl o osobności, przywołuje lęk i wstręt.

\section{Wieczny Tułacz}

Sogdiana, gdzie się kiedyś urodziłem

jako baktryjski Żyd, który pogardzał

${ }^{1}$ S. Pollak: Szlam. „Więź” 1991, nr 9, s. 134. Wiersz został zamieszczony również w pośmiertnym wyborze Próba oddalenia (Wstęp J. Hartwig. Warszawa 2008) i oznaczony jako jeden z liryków ze zbioru Wiersze wybrane i przekłady z $1954 \mathrm{r}$. W przywołanym tomie utworu jednak nie odnalazłam.

${ }^{2}$ Zob. M. Piechal: Notatnik poetycki Seweryna Pollaka. „Nowa Kultura” 1960, nr 48, s. 8.

${ }^{3}$ NoT: Poezja przyciszonego smutku. „Życie Literackie” 1960, nr 41, s. 10. 


\begin{abstract}
wszystkimi dookoła, ale który sam był przez tamtych wszystkich równie pogardzany, bo inny był. Bo brzydził się dotknięcia nieczystych. Ja dziś jeszcze myję ręce zbyt często - to mi pewno pozostało z owych lat. Jak ja kiedyś się brzydziłem! Oni śmierdzieli mi trupem, którego ptaki dziobami rwą, kruki i sępy, zezwłokiem mi śmierdzieli, co na wietrze zbutwiał do szczętu mięs. Brzydzę się dzisiaj poręczy tramwajowych i słuchawek w publicznych telefonach, co do ust do uszu moich głos cudzy donoszą, a same są bezgłośne i tak cudze, że muszę je rękawem z martwych otrzeć, zanim usłyszę żywy głos.
\end{abstract}

Sogdiana.

Zatarta $\mathrm{w}$ wiekach, ale nie $\mathrm{w}$ pamięci moich molekuł. Ja, wtedy tak obcy, nie mogłem czuć się czysty - wśród tych ciemnych, co świętym ogniem chcieli się oczyścić. Ja dzisiaj jeszcze noszę tamtą ciemność ogromnej śmierci sprzed tysiącleci, do dziś nie oczyszczony ${ }^{4}$.

Utożsamienie Pollaka jest ponadhistoryczne i ponadterytorialne. Kto urodził się Żydem, rodzi się nim wszędzie i przez wieki - „w pamięci molekuł” pozostaje to, co zaciera upływ czasu, co porządkują słowa. W utworze pamięć Zagłady jest nie tylko hiperbolizowana, ale i pseudonimowana. Miejsce i historyczny moment, do których odwołuje się poeta, to kraina leżąca na terenach dzisiejszego Uzbekistanu i Tadżykistanu oraz sto dwadzieścia lat funkcjonowania wielokulturowego królestwa greko-baktryjskiego (250-130 rok p.n.e.) $)^{5}$.

Tytułowa wieczność tułaczki jest powtarzalnością losów, powtarzalnością osobności. Tym, co ją umożliwia, jej ahistoryczne, alogiczne trwanie, wydaje się mechanizm obrzydzenia. Bo przecież „to nie brak czystości czy zdrowia sprawia, że coś się staje wstrętne; wstrętne jest to, co zaburza tożsamość, system, ład. Co nie przestrzega granic, miejsc, zasad"6. Obrzydzenie oddziela swoich od obcych. Pozwala na identyfikację. Analizując teksty Louis-Ferdinanda Céline’a

${ }^{4}$ S. Pollak: Wieczny Tułacz. W: Tenże: Lęk przestrzeni. Kraków 1981, s. 10.

${ }^{5}$ Moment wydania Lęku przestrzeni, z którego pochodzi Wieczny Tułacz, jest bliski wykopaliskom w Ajchanom, jednym z głównych ośrodków państwa greko-baktryjskiego. Miasto odkryto przypadkiem, w $1961 \mathrm{r}$. Wkrótce rozpoczęte wykopaliska zostały przerwane w $1979 \mathrm{r}$. $\mathrm{w}$ związku z radziecką interwencją w Afganistanie.

${ }^{6}$ J. Kristeva: Potega obrzydzenia. Esej o wstręcie. Przeł. M. Falski. Kraków 2007, s. 168. 
i rekonstruując ukryte w nich źródła odrazy warunkującej antysemityzm, Julia Kristeva pisze:

Żyd upewnia się o tym, że jest, że jest wszystkim i wszędzie - totalizując świat w jedną nieprzerwaną całość [...]. Skryty i posiadający klucz tajemnicy [...] sprawuje nieuchwytną władzę. Jego wszechobecność nie ogranicza się do przestrzeni, jest nie tylko na naszych ziemiach, ale także w naszej skórze, tak bliski, niemalże ten sam, ten, którego się nie odróżnia, który jest zawrotem tożsamości $i^{7}$.

Obawa przed połączeniem, utożsamieniem pobrzmiewa $\mathrm{w}$ wielu hasłach wyrażających niechęć do Żydów, w tym w niechlubnym, powracającym w Polsce postulacie „odżydzenia” struktur państwowych. W Wiecznym Tułaczu odczucie odrazy towarzyszy jednak przede wszystkim tytułowej postaci. Jednostka zostaje odrzucona i jest pogardzana „przez wszystkich”. Adresaci wstrętu, choćby dojmującego, nienawistnego, są z kolei uprzywilejowani. Odrazę kieruje się przeciw ich statusowi, przeciw ich „swojości” i własnej „obcości”. Jest bronią niezdolną do obrony. W obrzydzeniu Tułacza tkwi jednak coś jeszcze - autor odwraca spodziewany kierunek wstrętu, co pozwala na demaskację i dekonstrukcję antysemityzmu. Ujawniona, zaakcentowana, a nawet przerysowana odraza („Oni śmierdzieli mi trupem [...] zezwłokiem mi śmierdzieli”) staje się wyrazem bezradności wobec krzywdy wykluczenia.

Znaczący jest tu wstręt do słuchawek publicznych telefonów, noszących ślady obcego dotyku i czyichś słów. Być może w tej niechęci została zaszyfrowana okupacyjna trauma Pollaka, zmuszonego do ukrywania się, żyjącego w strachu przed zadenuncjowaniem. Wskazywałyby na to anonimowe, "martwe głosy” ścierane ze słuchawki i słowo, które nie jest niewinne, nawet gdy takim się wydaje - „donoszą”, podkreślone w wygłosie jednego z wersów.

Obrzydzenie Wiecznego Tułacza to nie tylko obawa przed utratą siebie. To odpowiedź na ranę historii.

Rodzaj oddzielności i obcości - wybranej? a może narzuconej? - znajduje wyraz w recepcji twórczości Pollaka. Jego liryka była oceniana różnie. Zarzucano jej brak oryginalności, niemożność wyjścia poza obowiązującą konwencję bojaźliwość w obrazowaniu9. Ceniono w niej natomiast poetycką ścisłość, uczciwość (umiejętność nazwania „nieskłamanej codzienności i nieskłamanego patosu"10), konsekwentne, z biegiem czasu coraz bardziej zaskakujące, anachro-

\footnotetext{
7 Tamże.

${ }^{8}$ M. Chrzanowski: Wybór wierszy Seweryna Pollaka. „Nowe Książki” 1976, nr 4, s. 236.

${ }^{9}$ NoT: Poezja..., s. 10.

10 J. Kwiatкоwsкi: „Wiersze wybrane” - Pollaka. „Życie Literackie” 1955, nr 24, s. 10.
} 
niczne wybory artystyczne (trwanie przy regularnych rymach, preferowanie czterowersowej strofy, troskę o rytmiczną harmonię). Michał Głowiński pisze o Okach sieci - tomie, który krytyka przyjęła najcieplej:

Pollak jakby prowokuje czytelnika, przyzwyczajonego już do rewolucji formalnej, spowodowanej przez awangardę, stosowaniem chwytów już w poezji dzisiejszej prawie się nie pojawiających [...]. Ta przyrodzona tradycyjność struktury językowej przylega w pełni do refleksyjności omawianych tu wierszy - trudno sobie wręcz wyobrazić, żeby refleksyjność, tak jak pojmuje ją Pollak, dała się ująć środkami poetyki Przybosia, Bieńkowskiego czy Białoszewskiego ${ }^{11}$.

Sam Pollak miał do swojej poezji stosunek ambiwalentny. W liście do przyszłej żony Wandy Grodzieńskiej przyznaje w odpowiedzi na jej przytyk: „Masz rację - $\mathrm{z}$ tęsknoty można zostać grafomanem. Tobie to nie grozi, bo ty masz talent - ale ja wierszy nie powinienem pisać"12. Jest w tym wyznaniu coś więcej niż komplement wyrażony kosztem oceny własnej twórczości. Ponad dwadzieścia lat później zwierza się żonie:

Wiesz najlepiej, że ja czuję się jedynie wtedy dobrze, gdy grafomanię swoje wierszyki. Wiesz - takie o życiu, o naturze, o radości istnienia i zgodzie na śmierć, ale późną, bardzo późną, taką trochę teoretyczną ${ }^{13}$.

O tym, czym dla Pollaka jest tworzenie poezji, na przekór niektórym recenzjom (cudzym i własnym), najlepiej świadczy może wspomnienie Andrzeja Brauna:

Kiedy rozmawiałem z nim ostatni raz, po czterdziestu kilku latach naszej przyjaźni, pytając zdawkowo, jak się czuje, powiedział ze swym zażenowanym i łagodnym uśmiechem: „Wiesz, czuję się dobrze, tylko nie mogę już pisać wierszy”. Zrozumiałem, co to dla niego znaczy ${ }^{14}$.

Pollak traktuje twórczość poetycką jednocześnie osobiście i bezkompromisowo. Jest wierny swoim wyborom. Krytykom odpisuje:

Raz pewien krytyk-kameleon mówił, że cudzym blaskiem świecę.

${ }^{11}$ M. GŁowiński: Poezja refleksyjna. „Twórczość” 1960, nr 12, s. 121.

${ }_{12}$ List Seweryna Pollaka do Wandy Grodzieńskiej, 22 II 1930. Korespondencja małżeństwa Wandy z Grodzieńskich i Seweryna Pollaków. T. 1. Magazyn Rękopisów Biblioteki Narodowej w Warszawie, rkps akc. 15210.

${ }^{13}$ List Seweryna Pollaka do Wandy Grodzieńskiej, 20 VIII 1954. Korespondencja małżeństwa Wandy z Grodzieńskich i Seweryna Pollaków. T. 2. Magazyn Rękopisów Biblioteki Narodowej w Warszawie, rkps akc. 15210.

${ }^{14}$ A. BRaun: Seweryn Pollak (tekst wygtoszony na pogrzebie Seweryna Pollaka 31 grudnia 1987 r.w Warszawie). „Więź” 1988, nr 5, s. 95. 
Zgoda, gdy za wieszczami lecę, Spoglądam na dół, patrzę - gdzie on?

A tamten siedząc nad bajorkiem,

Słabym wachluje się jęzorkiem,

Dwunasta skóra mu linieje

Żółkiewszczy się, putramencieje -

Kameleonik, kamerdynio,

Co w sprytnym nosku dłubie palcem.

I cóż? Ja ptakiem, on... padalcem ${ }^{15}$.

W humorystycznej replice (niepozbawionej jednak śmiałości, biorąc pod uwagę kontekst towarzysko-polityczny ${ }^{16}$ ), co może zaskakujące, trudno doszukać się polemiki z uwagą krytyka (autor recenzji, skrywający się pod pseudonimem „Ironiczny”, zarzucał Pollakowi, że „tom jego świeci odbitym księżycowym blaskiem"17). Poeta doskonale zdaje sobie sprawę z niedostatków warsztatu. W swoją twórczość wątpi chyba bardziej, niż powinien. Trudno jednak o docenienie własnych lirycznych prób, jeśli poezję postrzega się tak, jak w wierszu Pollaka Ze Szczipaczowa:

Ja wierzę w wiersze te jedynie,

Bez których ludzie żyć nie mogą ${ }^{18}$.

„Nie wiem, czy istnieje poeta, na którym by w sposób tak oczywisty i niezaprzeczalny zemściła się niewiara we własne siły, we własną wizję" - pisze Jerzy Kwiatkowski ${ }^{19}$ w recenzji Wierszy wybranych. Znakomitym kontekstem tej uwagi wydaje się, powtarzana w wielu wypowiedziach Pollaka, myśl o pracy translatorskiej, która „Zżera” twórczość własną ${ }^{20}$. A może jeszcze lepszym - przypisywane mu powiedzenie: „Żyd wieczny tłumacz”.

Swoją poezję Pollak traktował inaczej niż tę, którą przekładał i promował ${ }^{21}$. Wyznaczył dla siebie skromniejszą rolę - towarzyszenie temu, co wyznacza

15 S. Pollak: Odpowiedź pewnemu krytykowi. „Nowa Kultura” 1953, nr 4, s. 8.

${ }^{16} \mathrm{~W}$ momencie powstania wiersza Jerzy Putrament pracował jako sekretarz generalny w Zarządzie Głównym Związku Literatów Polskich. Drugiego z adresatów złośliwości, Stefana Żółkiewskiego, Pollak znał już z czasów studenckich. W latach 1945-1948 współpracowali przy „Kuźnicy” - Żółkiewski był redaktorem naczelnym pisma, Pollak - członkiem zespołu redakcyjnego.

17 Cyt. za: Recenzja warszawska na cenzurowanym. „Nowa Kultura” 1953, nr 4, s. 8.

18 Za: W. SAdkowski: Poezja słów ważkich. „Życie Literackie” 1953, nr 2, s. 4.

19 J. Kwiatkowski: „Wiersze wybrane”..., s. 10.

20 Z. Dmitroca: O Sewerynie Pollaku i jego kręu. „Kresy” 2008, nr 1-2, s. 183.

${ }^{21}$ Pollak był znawcą literatury rosyjskiej i wybitnym tłumaczem, który przybliżył polskim czytelnikom twórczość m.in.: Borysa Pasternaka, Anny Achmatowej, Aleksandra Błoka, Mariny Cwitajewej, Michała Lermontowa czy Aleksandra Puszkina. Odkrył również wielki talent Iosifa Brodskiego, na długo zanim poeta zyskał międzynarodową sławę. 
główny nurt. Pisał osobno, na przekór, czasem niezręcznie, staroświecko - ale też w zgodzie z własnym przekonaniem. Pollak potrafił zdecydować o własnej marginalności. Milczenie okazało się dla niego znacznie trudniejsze.

\section{„[...] jestem z Twej spalonej rodziny” Żydowscy adresaci}

Seweryn Pollak urodził się w 1906 roku w Warszawie ${ }^{22}$. Był synem Marii z Sobolów i Grzegorza Pollaka. O ile kilku informacji o matce poety dostarcza jego korespondencja z Wandą Grodzieńską, o tyle losy ojca ustalić znacznie trudniej. O Grzegorzu Pollaku wiadomo niewiele ponad to, że był znanym w dwudziestoleciu międzywojennym artystą malarzem. Przy ulicy Leszno 8 prowadził atelier portretów, ale najchętniej malował kwiaty. Do dziś na internetowych aukcjach można kupić jego martwe natury, utrzymane w ciepłych barwach, rozjaśnione słońcem. Zginął śmiercią samobójczą we Lwowie wiosną 1943 roku (dzień i miesiąc śmierci pozostają nieustalone), a jego grób na warszawskich Powązkach jest mogiłą symboliczną ${ }^{23}$. Z krótkiego wspomnienia Pollaka o ojcu, odnotowanego $\mathrm{w}$ jednym $\mathrm{z}$ wywiadów, wynika, że autor Wyprawy za trzy morza zawdzięczał mu wybór życiowej - a może i poetyckiej - drogi.

Język rosyjski poznałem w domu. Mój ojciec, który był malarzem - nota bene uczniem Repina - kształcił się w Rosji i miał od młodych lat kult dla literatury, dla poezji rosyjskiej. Co prawda myślał, że będę się raczej zajmował prozą - namawiał mnie, abym pisał - oczywiście po polsku - krótkie opowiadania, takie w stylu Czechowa, ale nic z tego nie wyszło ${ }^{24}$.

Znacznie więcej o ojcu Pollak mówi w poezji. Z 1954 roku pochodzi cykl wierszy stanowiących świadectwo wnikliwego, empatycznego wczytania się w jego losy. O utworach tych Julia Hartwig pisze:

Niełatwe to było zadanie ukazać poprzez wiersz życie człowieka równie bliskiego, któremu dane było przeżyć dramat podwójny: nieznalezionego miejsca

${ }^{22}$ Informację o tym, że Seweryn Pollak urodził się pod koniec 1906 r., ale jego narodziny wpisano do ksiąg już w 1907 r., podaje Adam Pomorski. Zob. Tenże: O Sewerynie Pollaku (1906-1988) w dziesiąta rocznicę śmierci. „Zeszyty Literackie” 1998, z. 62, s. 143.

${ }^{23}$ Słownik artystów polskich i obcych w Polsce działających. T. 7. Red. U. MakowsKa. Warszawa 2003, s. 371.

${ }^{24}$ S. Pollak: Tłumaczenie - to sprawa wyboru. Rozmawiała A. Sobecka. „Nadodrze” 1975, nr 22, s. 4. 
na świecie - którym stała się Polska po wygnaniu z Rosji - i dramat niespełnionych pragnień artysty-malarza, marzącego o wielkiej sztuce, żywiącego cześć dla Cezanne’a i tęskniącego za swobodą francuskiej cyganerii, z którą nigdy się nie zetknął.

Nostalgia, poczucie pustki i towarzyszącej ojcu poety obcości znalazły pełen czułości i zrozumienia wyraz w tym wierszu napisanym przez syna. Nie po raz pierwszy przekonać się tu możemy, jak nasycenie utworu poetyckiego uczuciem przybliża odbiór i zacieśnia więź między poetą i czytelnikiem²5.

Z opinią Hartwig, zauważającej związek osobistego tonu wierszy z żywym kontaktem poety z odbiorcą, współbrzmią opinie krytyków. Utwory z cyklu o ojcu należą do najbardziej docenianych w twórczości Pollaka ${ }^{26}$. Jego głos wydaje się w nich wyraźny, jakby mówił z bliska.
Odwety
[...]
Tak, to na pewno tutaj - w bezimiennym grobie nie zamknąłeś pamięci, ja wziąłem te schedy. Smutne dziedzictwo - pamięć straconego życia. Pamiętasz? Chciałeś ukraść powietrzu kolory, przeniknąć jego głębię, rozedrzeć ugory powietrznej bryły, aby ją stopić w błękicie. $[\ldots]$ Jakiż ty byłeś młody, gdy jasne kasztany lepkim pąkiem świeciły wieczorami w górze, jak pilnie przyglądałeś się architekturze tego nowego miasta - tutaj zakochany. W pamięci miałeś jeszcze dalekie przestrzenie pól naddnieprzańskich, wody sine i szerokie, a gdy zamknąłeś oczy, to przed twoim wzrokiem i blaskiem wody krata stawała - więzienie. O, oni byli mądrzy, długo nie trzymali, nie na wschód lecz na zachód pozwolili jechać, do zapomnianej ziemi $[\ldots]^{27}$.

W przytoczonym fragmencie poeta odnosi się między innymi do wydarzeń z około 1913 roku, kiedy Grzegorza Pollaka wygnano z Rosji. Zdaniem Wiktora Dłuskiego sprawa związana była z procesem Menachema Bejlisa, Żyda fałszywie oskarżonego o rytualny mord. Mężczyzna został uniewinniony - spędził jednak dwa lata w więzieniu i stał się ofiarą antysemickiej nagonki. Pollak jako korespondent polskiej prasy podczas procesu sądowego publicznie opowiedział

\footnotetext{
${ }^{25}$ Zob. J. Hartwig: Poezja Seweryna Pollaka. W: S. Pollak: Próba oddalenia..., s. 8.

${ }^{26}$ Zob. NoT: Poezja..., s. 10.

${ }^{27}$ S. Pollak: Odwety. W: TenżE: Oka sieci. Warszawa 1960, s. 7-8.
} 
się po jego stronie. Spór między dwiema frakcjami - wspierającą Bejlisa i atakującą go - przybrał takie rozmiary, że artysta, jako przedstawiciel grupy mającej mniejsze wpływy, został wydalony z kraju (a może, czego nie wyklucza Dłuski, uciekł, obawiając się o swoje życie $)^{28}$.

To, co w wierszach o ojcu wydaje się szczególne, to próba - zaskakująco skrupulatnego jak na poezję - odnotowania wydarzeń i doświadczeń, uporządkowania ich $\mathrm{w}$ takim sensie, $\mathrm{w}$ jakim zadanie to podejmuje życiorys. Cykl Pollaka można by więc nazwać poetycką biografią. Jest ona nieco chropowata i traci niekiedy liryzm. Dzieje się tak tam, gdzie wymóg ścisłości i prawdziwości ogranicza swobodę obrazowania. Te jednak fragmenty wiersza są interesujące najbardziej - wskazują bowiem, że wierność faktom, biograficzna dyscyplina są przez poetę traktowane priorytetowo. Wrażenie autentyczności, szczerości za cenę estetyczności sprzyja więzi między poetą i czytelnikiem. Niezręcznościami, zaburzeniami rytmu Pollak prowokuje lekturę empatyczną.

Trudna biografia ojca oznacza konieczność zmierzenia się z wymagającą schedą. Dla poety to nie tylko "pamięć straconego życia”, niezrealizowane plany, ambicje i marzenia. Pollak-syn przyjmuje też odziedziczone po ojcu wykluczenie. Pełne czułości zrozumienie, z którym podejmuje ten temat, zdradza podobieństwa doświadczeń:

\section{$[\ldots]$}

Ty wszędzie będziesz obcy, biedny cudzoziemcze, i zewsząd zalewany drobnych spraw potokiem, i do końca tę szarość będziesz miał przed okiem, której nie przedrą ni błyskawice, ni tęcze ${ }^{29}$. $[\ldots]$

Faktograficzna ścisłość Wierszy o ojcu w pewnym momencie zostaje zawieszona. Tam, gdzie autor życiorysu pisałby o kresie życia, Pollak nieoczekiwanie zmienia strategię. Rezygnuje z dosłowności. Szuka metafor, obrazów zastępczych.

$[\ldots]$

Bieleje w parku trawa pierwszym szronem ścięta, nad stawem jakaś ciemna majaczy się postać:

- Nie mogę tam pojechać, nie mogę tu zostać... -

Zostałeś.

Nikt nie wiedział - i nikt nie pamięta ${ }^{30}$.

${ }^{28}$ W. Dłuski (tłumacz z języków rosyjskiego i francuskiego, laureat Nagrody Literackiej GDYNIA, zięć Seweryna Pollaka) w prywatnej rozmowie (20 lutego 2019 r.). Serdecznie dziękuję Panu Wiktorowi za niezawodną pomoc.

${ }^{29}$ S. Pollak: Odwety..., s. 9.

${ }^{30}$ Tamże. 
Poeta pozwala czytelnikowi jedynie na domysły. Ze śmiercią ojca próbuje się zmierzyć w jeszcze jednym utworze:

Na śnieżne zimy, na obłoki, na nagłą radość, na marzenia rzuciłeś klątwę zapomnienia, słysząc najeźdźców ciężkie kroki.

Wierzyłeś tylko w twarde słowa przekleństwa, w gniewne złorzeczenia, które nad wrogiem jak grobowa płyta zatrzasną głąb milczenia.

Tyś się zarzekał nawet wspomnień i trując się w swej bezradności, czekałeś. Wiatr odwiewał płomień zbyt szybko, by rozpocząć pościg.

Na próżno. Byłeś jak latarnia oślepła w nocy zaciemnienia, gdy światło w jedno miejsce zgarnia, skrzętnie skrywając blask promienia.

Oto świadectwo ostateczne, prawdziwe aż do krwi stężenia. Ono za tobą pójdzie wiecznie jak echo niedopowiedzenia ${ }^{31}$.

„Echo niedopowiedzenia” wydaje się formułą najlepiej podsumowującą zarówno tragiczne losy Grzegorza Pollaka, jak i kierunek zaprezentowanego we fragmentach poetyckiego biogramu - śmiałego w rozpoznaniach, ale niezdolnego unieść ciężaru wspomnień. Warto dodać, że Seweryn Pollak przywołuje ojca również w innych wierszach: w Cieniach, gdy kreśli obraz dzieciństwa („Pamiętam: nie lubiłem czyścić ojcu palety”) ${ }^{32}$, i we Wrastaniu w kamień („Już teraz trudno mi pomyśleć [...], że mój ojciec zabraniał mi kiedyś palić papierosy") ${ }^{33}$. Co ciekawe, o matce w poezji milczy - choć przecież żywą troskę o nią rejestruje korespondencja poety z żoną.

Zanim odniosę się do kolejnych utworów Seweryna Pollaka przywołujących wątek jego pochodzenia, wrócę do ustaleń biograficznych.

${ }^{31}$ S. Pollak: ${ }^{* *}$ Na śnieżne zimy, na obłoki. W: TenżE: Oka sieci..., s. 17.

32 S. Pollak: Cienie. W: Tenże: Przenikanie. Warszawa 1965, s. 10.

${ }^{33}$ S. Pollak: Wrastanie w kamień. W: TenżE: Przenikanie..., s. 53. 
W latach 1927-1934 Pollak i Grodzieńska studiowali filologię polską na Uniwersytecie Warszawskim ${ }^{34}$. Bliższą znajomość zawarli prawdopodobnie w 1929 roku, podczas pobytu w Milanówku. Z listów, które pisali w tym okresie, wynika, że niemal natychmiast zdecydowali się pobrać, choć plany ślubne utrzymywali $\mathrm{w}$ tajemnicy, przynajmniej przed znajomymi, jeszcze zimą $1930 \mathrm{roku}^{35}$. Zdaniem Dłuskiego nieujawnianie informacji o uroczystości wiązało się prawdopodobnie z sytuacją materialną narzeczonych i brakiem możliwości zorganizowania wesela.

Ślub odbył się 2 sierpnia 1930 roku w kościele ewangelicko-augsburskim przy placu Małachowskiego. Wyznania protestanckiego byli Grodzieńscy - matka Wandy, Róża, której panieńskie nazwisko brzmiało Teszner, pochodziła z żydowskiej rodziny. Konwersja na protestantyzm okazała się dla niej łatwiejsza niż na katolicyzm. Wanda Grodzieńska pozostała przy swoim wyznaniu również po wojnie - została pochowana na cmentarzu ewangelicko-augsburskim przy ulicy Młynarskiej w Warszawie.

Grodzieńska i Pollak należeli do Koła Polonistów Słuchaczów Uniwersytetu Warszawskiego, środowiska wyjątkowo prężnego naukowo - i wyjątkowo twórczego. Kazimierz Budzyk, jego członek, wspomina po latach: „W czasach kiedy żaden $\mathrm{z}$ wybitnych profesorów polonistyki nie potrafił stworzyć własnej szkoły badawczej, my tworzyliśmy ją bez profesora" ${ }^{36}$. W innym tekście dodaje:

Były to czasy niezapomniane, okres zakładający podwaliny dla nowatorstwa we wszystkich niemal specjalizacjach polonistycznych. Dziś to już prawie nie do wiary: organizacja studencka, pozbawiona środków finansowych i zwalczana przez niektórych przedstawicieli profesury uniwersyteckiej, stworzyła i zaczęła realizować perspektywiczny plan badań naukowych, prowadzonych w oparciu o najnowsze zdobycze nauki europejskiej ${ }^{37}$.

${ }^{34}$ We wcześniejszej edukacji przyszłego poety uwagę zwracają częste zmiany szkół: naukę rozpoczął jako dwunastolatek w Gimnazjum im. T. Rejtana. Placówka ta, mieszcząca się w centrum miasta, była wówczas jedyną w Warszawie z tak szeroką ofertą języków klasycznych (greka i łacina). Rok później Pollak trafił do Gimnazjum im. J. Lelewela (uczył się tam w latach 19201925). Maturę natomiast zdał w Gimnazjum Władysława IV - położonym na Pradze, w zastanawiająco niekorzystnej odległości od najbardziej prawdopodobnego miejsca zamieszkania. Czy częste zmiany szkół miały związek z nasilającymi się w Warszawie nastrojami antysemickimi? A może z trudną sytuacją materialną Pollaków? Rozważania na ten temat, wobec braku źródeł, pozostają wyłącznie hipotezami. Wątek szkolnych przenosin pojawia się jednak w biografiach wielu Żydów uczących się w przedwojennej Polsce. Na temat edukacji poety zob. [E. GŁĘBICKA:] Pollak Seweryn. W: Współcześni polscy pisarze i badacze literatury. Słownik biobibliograficzny. Oprac. zespół pod red. J. Czachowskiej i A. Sząagan. T. 6: N-P. Warszawa 1996, s. 434.

${ }^{35}$ Zob. Korespondencja małżeństwa Wandy z Grodzieńskich i Seweryna Pollaków. T. 1...

${ }^{36}$ K. Budzy K: Stefania Knispel-Wróblowa (22 XI 1911-2 II 1963): wspomnienie. „Pamiętnik Literacki” 1963, R. 54, z. 3, s. 255. Wróblowej, która pełniła funkcję sekretarki w Kole i przez jego członków była wspominana jako wyją̧tkowo życzliwa i rzetelna osoba, wiersz poświęcił również Pollak. Zob. S. Pollak: Dickens. W: TenżE: Godzina życia. Łódź 1946, s. 38.

${ }^{37}$ K. Budzy : O Franciszku Siedleckim wspomnienie. „Pamiętnik Literacki” 1946, R. 36, z. 3-4, s. 376 . 
Zainicjowany przez młodych polonistów ruch był w dużej mierze kontestatorski i kierował się przeciw pozytywistycznym metodom badawczym, wciąż jeszcze żywym na Uniwersytecie (przeciw wpływom biografistyki, psychologi$\mathrm{zmu}$ ). Równocześnie oswajał najnowsze osiągnięcia z zakresu metodologii badań literackich - szczególnie rosyjskiego formalizmu i czeskiego strukturalizmu ${ }^{38}$. Koło dzieliło się na kilka sekcji: teorii literatury i metodologii badań literackich, której kierownictwo objął Stefan Żółkiewski, teatrologii pod kierunkiem Józefa Kuroczyckiego, socjologii literatury, prowadzona przez Dawida Hopensztanda, i krytyki literackiej, założona przez Ludwika Frydego ${ }^{39}$. O funkcjonowaniu tych działów Ryszard Matuszewski pisze:

W Kole Polonistów rej wodzili młodzi ludzie o dużych ambicjach intelektualnych i naukowych. Kilku z nich, studentów z niewiele starszych od nas roczników, prowadziło zajęcia ze skupionymi wokół siebie grupkami młodszych kolegów, sugerując im lekturę naukowych książek, często spoza zakresu tych, które polecali im ówcześni wykładowcy na warszawskiej polonistyce ${ }^{40}$.

Bardzo ważną postacią w środowisku był Franciszek Siedlecki, bliski przyjaciel Pollaka:

On był duszą całej grupy, on pierwszy uzyskał nieprzeciętne osiągnięcia pozytywne w dziedzinie, którą reprezentował i przez to był wzorem nam wszystkim, którzyśmy przecie wyrastali dopiero $\mathrm{z}$ atmosfery seminarium, on nadawał ton każdemu wystąpieniu na zewnątrz, on wreszcie organizował i prowadził naszą studencką jeszcze na początku akcję wydawniczą ${ }^{41}$.

Siedlecki zasłynął między innymi jako wynalazca terminu „literaturoznawstwo" "42. Mając dwadzieścia osiem lat, opublikował w „Wiadomościach Literackich" jeden z pierwszych w Polsce tekstów omawiających prace Romana Jakobsona i Praskiego Koła Lingwistycznego ${ }^{43}$. Badaczowi, który zmarł w czasie wojny, Pollak poświęcił poruszający wiersz List do przyjaciela ${ }^{44}$.

Poszukując bliższych informacji o funkcjonowaniu Koła Polonistów, Danuta Ulicka zauważa źródłowe niedostatki:

${ }^{38}$ P. Gienowski: Struktury historii. O czeskim projekcie dziejów literatury na tle recepcji praskiego strukturalizmu w Polsce. Kraków 2013, s. 80-81.

${ }^{39}$ K. Budzy K: O Franciszku Siedleckim..., s. 377.

${ }^{40}$ R. Matuszewski: Chmury na pogodnym niebie. Warszawa 1998, s. 29.

${ }^{41}$ K. Budzy K: O Franciszku Siedleckim..., s. 376.

42 D. Ulicka: Tradycje nowoczesnego literaturoznawstwa polskiego. „Teksty Drugie” 2008, nr $1-2$, s. 210.

${ }^{43}$ P. GIERowsKi: Struktury historii..., s. 79.

${ }^{44}$ Zob. S. Pollak: List do przyjaciela. W: TenżE: Godzina życia..., s. 31-37. 
Wiedzy twardej, ścisłej i niepodważalnej niewiele o Kole zostało. Jako instytucja nieformalna nie prowadziło ono „ksiąg wieczystych”, a dokumenty, jakie być może powstawały, prawdopodobnie zaginęły w wojennej i powojennej zawierusze. Informacje, które przetrwały, to przede wszystkim wspomnienia bezpośrednich uczestników zaangażowanych ${ }^{45}$.

Ulicka nie ma jednak racji, gdy w dalszej części tekstu twierdzi, że Koło było organizacją nieoficjalną, która nie wręczała legitymacji ${ }^{46}$. Z dokumentów, jakie zachowały się w archiwum Grodzieńskiej, wynika, że Koło miało statut i zarząd, a także własne zbiory biblioteczne ${ }^{47}$. W teczce poetki znajdują się też dwie legitymacje członkowskie ze stemplami z logo instytucji oraz podpisami prezesa i sekretarza (lata 1931 i 1932). Wydaje się, że dokumenty Grodzieńskiej pozwalają rozwiać jeszcze jedną wątpliwość badaczy zajmujących się środowiskiem warszawskich polonistów - dotyczącą patrona Koła. Na zaświadczeniu o organizacji trzymiesięcznych kursów bibliotekarskich, wydanym poetce w 1929 roku, zachowała się nazwa: Koło Polonistów im. St. Żeromskiego.

Organizacja powszechnie uważana była za najbardziej lewicowe koło naukowe w stolicy ${ }^{48}$. Wielu jej członków żywiło sympatie komunistyczne, a polityczne nadzieje kierowało ku ZSRR. Grodzieńska i Pollak również byli zorientowani lewicowo. W życiorysie z 1948 roku poetka pisze:

W czasach uniwersyteckich, jakkolwiek nie byłam czynnym członkiem KPP, starałam się w miarę możności pomagać członkom partii, ukrywając w swoim domu towarzyszy partyjnych zagrożonych więzieniem i przechowując prasę propagandową ${ }^{49}$.

Autor Wypraw za trzy morza jeszcze w czasie nauki w gimnazjum, w 1924 roku, wstąpił do Związku Polskiej Młodzieży Socjalistycznej. Podczas studiów należał do Organizacji Młodzieży Socjalistycznej, a później do OMS „Życie” i do Międzynarodowej Organizacji Pomocy Rewolucjonistom ${ }^{50}$. O jego przekonaniach politycznych Braun mówi:

Seweryn Pollak był od wczesnych lat człowiekiem o lewicowych poglądach i miłośnikiem wielkiej literatury sąsiedniego, rosyjskiego narodu. Nie było w tym nic koniunkturalnego. I w złych, i w sprzyjających czasach pozostawał swym autentycznym skłonnościom wierny.

45 D. Ulicka: Tradycje..., s. 206.

46 Tamże, s. 214.

47 Zob. Dokumenty osobiste i rodzinne Wandy Grodzieńskiej: legitymacje, świadectwa, pisma urzędowe. Magazyn Rękopisów Biblioteki Narodowej w Warszawie, rkps akc. 15207.

48 Zob. R. Matuszewski: Chmury..., s. 29.

49 Dokumenty osobiste i rodzinne Wandy Grodzieńskiej...

50 [E. GŁĘBICKA:] Pollak Seweryn..., s. 434. 
Jeśli mówię o lewicowości, nie mam na myśli dyspozycyjności partyjnej czy proreżimowego służalstwa. Myślę o moralnej bliskości idei ${ }^{51}$.

Podobnie brzmi opinia Matuszewskiego, który poznał Pollaka w połowie lat 30.:

[...] młodzieńczy radykalizm Seweryna zapamiętałem [...] jako dość spokojny, daleki od fanatyzmu i miarkowany gustami literackimi, bo właśnie literatura była jego miłością pierwszą, a nie polityka, wobec której czuł zobowiązania natury przede wszystkim społeczno-moralnej ${ }^{52}$.

Narzeczeni czuli się silnie związani ze środowiskiem uniwersyteckim. Kiedy w lutym 1930 roku Pollak przebywał w Kliczewie pod Kuczborkiem, gdzie jako nauczyciel zatrudniony przez państwa Podczaskich (w listach nazywa ich „Dziedzicami”) zbierał środki na spłatę długów, narzeczona niemal codziennie przekazywała mu nowinki z życia uniwersyteckiego, szczególnie skrupulatnie informując o tym, co działo się w Kole. W bogatej korespondencji przyszłych małżonków zachowała się nawet sporządzona przez Grodzieńską nieformalna relacja z zebrania zarządu.

Teraz jest gwałtowna dyskusja na temat usunięcia słów: „narodowości polskiej” ze statutu. Meisner się rzuca okropnie [...]. Świetnie przemówił Kwiatkowski, kończąc humorystycznie: „wolę z żydami pracę naukową, niż narodowe majówki" ${ }^{33}$.

Organizacja, do której należeli Pollakowie, była jednym z nielicznych kół naukowych w stolicy, które w poczet swoich członków przyjmowało również Żydów ${ }^{54}$. Nastroje dominujące w połowie lat 30. na Uniwersytecie Matuszewski nazywa faszystowskimi i antysemickimi. Podkreśla popularność kręgów ONR-owskich i nacjonalistycznych ${ }^{55}$. Koło Polonistów było więc dla studentów żydowskiego pochodzenia środowiskiem w szczególny sposób atrakcyjnym: żywym i otwartym (nie tylko) intelektualnie, odpowiadającym na potrzeby przynależności i identyfikacji. Niewątpliwie miało duży wpływ na kształtowanie się przekonań i naukowych zainteresowań Pollaka. Zakreśliło także krąg jego najbliższych przyjaciół - późniejszych adresatów wierszy i literackich współpracowników.

${ }^{51}$ A. Braun: Seweryn Pollak..., s. 95.

52 R. Matuszewski: Pożegnanie Seweryna Pollaka. „Twórczość” 1988, nr 4, s. 135.

${ }^{53}$ List Wandy Grodzieńskiej do Seweryna Pollaka, 20 II 1930. Korespondencja małżeństwa Wandy z Grodzieńskich i Seweryna Pollaków. T. 1...

${ }^{54}$ Zob. Dzieje Uniwersytetu Warszawskiego 1915-1945. Red. P.M. Majewski. Warszawa 2016, s. $228-229$.

${ }^{55}$ E. Skrzynecka: Granice pamięci. Rzecz o Sewerynie Pollaku. Cz. 1. Audycja radiowa z udziałem zaproszonych gości z 28 maja 1989 r. Warszawa, Polskie Radio Program 2. 
Po studiach Pollak publikował między innymi w "Szpilkach” i w „Czarno na białem”. Od 1929 roku pracował jako sekretarz i bibliotekarz Stefana Napierskiego (Marka Eigera), a od 1934 roku jako sekretarz redakcji wydawanego przez niego "Ateneum”. Rozstali się z powodu różnic politycznych. Tłem konfliktu było zaangażowanie Pollaka w tworzenie lewicowego „Dziennika Popularnego”, $\mathrm{w}$ którym sprawował funkcję redaktora odpowiedzialnego i jednego $\mathrm{z}$ kierowników literackich. Czasopismo powstawało de facto pod patronatem KPP. W związku z likwidacją gazety w 1937 roku autora Przenikania aresztowano i aż do wybuchu wojny pozostawał pod nadzorem policji56.

W czasie okupacji Pollakowie musieli ukrywać się przed Niemcami ${ }^{57}$. Według Dłuskiego częste w tym okresie przeprowadzki rodziny wynikały ze składanych na poetę donosów. Matuszewski zwraca również uwagę na „semicki wygląd” Grodzieńskiej, wskazując, że właśnie dla niej pobyt w Warszawie stanowił największe zagrożenie ${ }^{58}$. Nie wszystkim bliskim poetki udało się umknąć Zagładzie. W odpowiedzi na pytanie z ankiety personalnej z 1952 roku Grodzieńska pisze: „Matka zamordowana przez hitlerowców z powodu dyskryminacji rasowych"59. To właśnie jej, Róży Grodzieńskiej, w 1943 roku Pollak zadedykował wiersz, który dokumentuje powstanie $\mathrm{w}$ warszawskim getcie:

Pióropusze

Pamięci R. G.

W dzień białodrzew pióropusz puszysty rozkłada,

Chmurą nasion obłoki nad sobą obsiewa -

Dymna smuga w ulicy unosi się blada,

Młodą zieleń płonącą rozwiewa.

Nocą świec pióropusze zakwitają z dala

I spadają na miasto w reflektorów błyskach -

Różowo się puszysta korona rozpala,

Bomb wstrzymując wstrząśnienia jak miękka kołyska.

Podpalona dzielnica dymi od tygodni,

Czarna chmura nad miastem jak zbrodnia się wznosi,

Białodrzew puchy liści co noc macza w zbrodni

I co dzień zbrodnię gasi w przedporannej rosie.

56 Zob. [E. GŁęвickA:] Pollak Seweryn..., s. 434.

57 Zapytany o pracę społeczną, konspiracyjną i wojskową podczas okupacji Pollak wymienia: współpracę z BIP AK, z „Przełomem” pod red. W. Bieńkowskiego i S. Żółkiewskiego, a w czasie powstania - z „Robotnikiem Mokotowskim”. W ostatnim z tytułów Pollak opublikował pod pseudonimem Andrzej Polski znany wiersz Mokotów. Zob. S. Pollak: Odpowiedzi na kwestionariusz biograficzny do niewydanego dzieła „Ludzie Polski Odrodzonej”. Magazyn Rękopisów Biblioteki Narodowej w Warszawie, rkps akc. 14705.

58 E. Skrzynecka: Granice pamięci...

59 Dokumenty osobiste i rodzinne Wandy Grodzieńskiej... 
Nieczuły świt majowy wschodzi mgłą zieloną

I oddycha ostatnim umarłych westchnieniem,

Gdy słoneczny pióropusz, barwą zemsty płonąc,

Wieńczy czoła morderców śmiertelnym promieniem ${ }^{60}$.

W listach wymienianych między Pollakiem a Grodzieńską wojna wydaje się czasem osobnym i oddzielnym, na zawsze zamkniętym. Można odnieść wrażenie, że lata milczenia były spowodowane dziwną pauzą historii, po której życie można podjąć od momentu, kiedy nastąpiła przerwa. We wzmiankowanym biogramie Grodzieńska pisze: „Od r. 1939 pięć lat wojennych uważam za wykreślone z życia" ${ }^{61}$. Dłuski wspomina, że także w prywatnych rozmowach Pollakowie nie wracali nigdy do okupacji.

Inaczej jednak jest w poezji. Liryka Pollaka zachowuje obrazy wojennych zniszczeń, pamięć o ofiarach i nieukaranej zbrodni. Wśród literackich świadectw powstania z 1943 roku Pióropusze są relacją wyjątkową. Nie korzystają z paraboli, nie szukają historycznych analogii. Tekst Pollaka ma walor wojennego reportażu. Zbrodnię dokumentuje na miejscu, „na żywo”. Ukazana tu zostaje perspektywa mieszkańca tzw. aryjskiej części Warszawy - spostrzeżone i utrwalone jest jedynie to, co widać w górze: unosząca się smuga, „czarna chmura”. W Pióropuszach przerażenie wywołuje obraz, tylko obraz - zanim jeszcze zyska pełne znaczenie. O losie ofiar nikt nie zdążył przecież opowiedzieć, a najstraszliwsza prawda pozostaje domysłem. Pollak notuje więc: czerń dymu, biały puch kwitnącej topoli - gwałt na wiośnie, walkę życia ze śmiercią ${ }^{62}$.

Szczegółów dotyczących losów Grodzieńskiej Pollakowie nigdy nie poznali. Wiadomo, że podczas wojny żyła w ukryciu. Dłuski przypuszcza, że została wydana Niemcom i zginęła w getcie.

Wiele utworów Pollaka przywołujących temat Zagłady ma adresatów (albo zawiera dedykacje). Poezja autora $O k$ sieci wydaje się przestrzenią rozmowy z tymi, których nie ma, i z tymi, którzy ocaleli - ale na zawsze już skazani są na obcość. Temat wykluczającego działania traumy Pollak podejmuje w wierszu Do milczącej, dedykowanym Marii Szczepańskiej ${ }^{63}$ :

60 S. Pollak: Pióropusze. W: Tenże: Godzina życia..., s. 10.

${ }^{61}$ Dokumenty osobiste i rodzinne Wandy Grodzieńskiej...

62 Unoszący się nad płonącym gettem czarny „śnieg” - zmieszane z dymem pierze i puch owocujących topoli - to obraz, który pojawia się w wielu poetyckich dokumentach tego okresu. Najsłynniejsze są chyba „czarne latawce” w Campo di Fiori Czesława Miłosza. O „Chmurach rozprutych poduszek i obłokach pierzyn”, lepiących się do rąk wraz z krwią, pisze też Zuzanna Ginczanka w inc. ${ }^{* * *}$ Non omnis moriar. Zob. K. Kuczyńska-Koschany: (Nie)topika Zagłady w NN „Opowieściach zasłyszanych”. „Narracje o Zagładzie” 2016, nr 2, s. 56.

63 Adresatka wiersza to chyba Maria Bielicka-Szczepańska (1909-1989), aktorka i śpiewaczka, była więźniarka obozów na Majdanku i w Auschwitz. 
$[\ldots]$

A ty w ciemności zamykałaś oczy

i widziałaś

siostrę, co jak białodrzew na wiosnę

dymem nasion uniosła się w powietrze przez komin kre-

matorium,

i brata, który dostał kulę w tył głowy,

i ojca, co zląkł się niemieckiej śmierci i rozpruł sobie

brzuch,

i teściową widziałaś, która zginęła bez wieści.

- Nie myśl o nich - mówili -

to cienie przeszłości,

smutnej przeszłości,

która się już nie powtórzy.

$[\ldots]^{64}$

W utworze pojawia się, znany z Pióropuszy, obraz kwitnącego białodrzewu. Wizja topoli stała się dla Pollaka rodzajem natręctwa, powracającym skojarzeniem „płonącej dzielnicy” - jakby obserwacja likwidacji getta spowodowała uraz wyobraźni polegający na trwałym związaniu się dwóch obrazów. Poeta mówi za milczącą, która, zamykając oczy, widzi wciąż te same przerażające sceny. Rozumie ją, ponieważ sam nie potrafi się od nich uwolnić. Wie, że „cienie przeszłości” nie odchodzą, a przeszłość uparcie się powtarza. Konsekwentne adresowanie wojennych wierszy do tych, którzy dzielą z Pollakiem traumę Zagłady, wydaje się więc nie tylko wyrazem empatii, ale też jej poszukiwaniem - próbą odnalezienia społecznego kontekstu, w jakim alienujące doświadczenia nie będą wykluczały, a zbudują porozumienie.

W poezji Pollak mówi to, co pomija w prozie. Twórczość liryczna stanowi rodzaj „bocznej odnogi” pracowitego życia tłumacza - to jego „drugie życie” literackie, w którym ujawnia się to, co wyparte, a co konieczne do wypowiedzenia. Chyba dlatego własna poezja, choćby „zżerana” przez tę tłumaczoną, mniej ceniona, niepoddająca się modom, była dla Pollaka tak ważna. Istotne w niej miejsce zajmują wiersze zawracające ku Zagładzie, aktualizujące poczucie zagrożenia i obcości. Właśnie tam, w utworach rozdrapujących rany pamięci, dyktowanych przez lęk, rozpoznanie siebie jest przenikliwe i śmiałe, a poetyckie „ja” - najwyraźniejsze.

Lądowanie w maju

Ja, który stałem pod ścianą godzin

(pomnóż pięć lat, trzy miesiące i ileś tam dni

${ }^{64}$ S. Pollak: Do milczacej (Marii Szczepańskiej). W: Tenże: Oka sieci..., s. 18-19. 
przez dni, godziny i skurcze lęku), ja, który nie strzelałem, ja, do którego strzelano, chodzę jak obłok i jestem tylko obłokiem przeszytym wibrującym propellerem. $[\ldots]^{65}$

\section{Bibliografia}

Braun A.: Seweryn Pollak (tekst wygłoszony na pogrzebie Seweryna Pollaka 31 grudnia 1987 r. w Warszawie). „Więź” 1988, nr 5, s. 95.

Dmitroca Z.: O Sewerynie Pollaku i jego kregu. „Kresy” 2008, nr 1-2, s. 182-186.

Dokumenty osobiste i rodzinne Wandy Grodzieńskiej: legitymacje, świadectwa, pisma urzędowe. Magazyn Rękopisów Biblioteki Narodowej w Warszawie, rkps akc. 15207. Dzieje Uniwersytetu Warszawskiego 1915-1945. Red. P.M. MAJEwsKi. Warszawa 2016.

Engelking L.: Seweryn Pollak 1907-1987. „Literatura na Świecie” 1988, nr 3, s. 356-359.

[GıęвICKa E.:] Pollak Seweryn. W: Współcześni polscy pisarze i badacze literatury. Słownik biobibliograficzny. Oprac. zespół pod red. J. Czachowskiej i A. SzaŁagan. T. 6: N-P. Warszawa 1996, s. 434-440.

GŁowiński M.: Poezja refleksyjna. „Twórczość” 1960, nr 12, s. 120-125.

Hartwig J.: Poezja Seweryna Pollaka. W: S. Pollak: Próba oddalenia. Wstęp J. HartWIG. Warszawa 2008, s. 5-15.

KARCZEWsKa W.: Listy do Seweryna. Zebrał, wprowadzeniem i komentarzami opatrzył K. SAMSEL. Szczecin 2002.

Korespondencja małżeństwa Wandy z Grodzieńskich i Seweryna Pollaków. T. 1. Magazyn Rękopisów Biblioteki Narodowej w Warszawie, rkps akc. 15210.

Korespondencja małżeństwa Wandy z Grodzieńskich i Seweryna Pollaków. T. 2. Magazyn Rękopisów Biblioteki Narodowej w Warszawie, rkps akc. 15210.

Kuczyńska-Koschany K.: (Nie)topika Zagłady w NN „Opowieściach zastyszanych”. „Narracje o Zagładzie” 2016, nr 2, s. 50-62.

Kwiatkowski J.: „Wiersze wybrane” - Pollaka. „Życie Literackie” 1955, nr 24, s. 10.

Matuszewski R.: Chmury na pogodnym niebie. Warszawa 1998.

Matuszewski R.: Pożegnanie Seweryna Pollaka. „Twórczość” 1988, nr 4, s. 135-138.

NoT: Poezja przyciszonego smutku. „Życie Literackie” 1960, nr 41, s. 10.

Pollak S.: Bezsenność. Wiersze dawne i nowe. Kraków 1975.

Pollak S.: Godzina życia. Łódź 1946.

Pollak S.: Lęk przestrzeni. Kraków 1981.

Pollak S.: Odpowiedzi na kwestionariusz biograficzny do niewydanego dzieła „Ludzie Polski Odrodzonej”. Magazyn Rękopisów Biblioteki Narodowej w Warszawie, rkps akc. 14705.

${ }^{65}$ S. Pollak: Lądowanie w maju. W: TenżE: Przenikanie..., s. 35. 
Pollak S.: Oka sieci. Warszawa 1960.

Pollak S.: Pocisk i słowo. Warszawa 1952.

Pollak S.: Próba oddalenia. Wstęp J. Hartwig. Warszawa 2008.

Pollak S.: Przenikanie. Warszawa 1965.

Pollak S.: Wiersze wybrane i przekłady. Warszawa 1954.

Skrzynecka E.: Granice pamięci. Rzecz o Sewerynie Pollaku. Cz. 1. Audycja radiowa z udziałem zaproszonych gości z 28 maja 1989 r. Warszawa, Polskie Radio Program 2 .

Agata Szulc-Woźniak

\section{Recalling (the Jewishness of) Seweryn Pollak}

\section{Summary}

This article focuses on Seweryn Pollak's poetry, despite him being known first and foremost as an essayist and translator. Although meeting mixed and negative reviews (including his own), Pollak's poetry is not only a space where personal and fascinating accounts, memories, conversations with the loved ones, and farewells collide, but also the precise genre which the author chooses to talk of his Jewish ancestry, which is left unmentioned in his narrative works, including those addressed to his family and friends. Among Pollak's poems, there are texts devoted to the Shoah that actualise the sense of danger and alienation; these painful recollections, although dictated by fear, happen to be the poems where self-reflection becomes sharp and thorough, while the poetic persona - predominant.

Searching for an insightful perspective on Pollak and his work, this article turns to his captivating handwritten texts with a special emphasis put on the collections of letters exchanged between him and his wife, Wanda Grodzieńska.

Key words: Seweryn Pollak, Grzegorz Pollak, Wanda Grodzieńska, poetry, Jewish identity, The Warsaw Ghetto Uprising, Circle of Polish Philology Students of the University of Warsaw 